\title{
Masseteric-Facial Anastomosis: A Report of Three Cases
}

\section{Anastomose massetérico-facial: Um relato de três casos}

\author{
Breno Alexander Bispo ${ }^{10}$ Paulo Eduardo Albuquerque Zito Raffa ${ }^{2(-)}$ \\ Pedro Henrique Simm Pires de Aguiar ${ }^{3(0)}$ André Alexandre Bocchi ${ }^{1}$

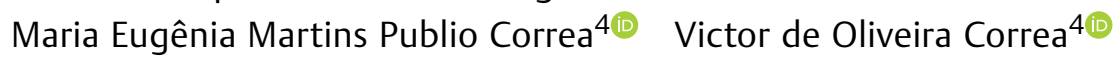 \\ Carlos Alberto de Almeida Castro Junior ${ }^{5(1)}$ Paulo Henrique Pires de Aguiar6,7,8(0) \\ Roberto Sergio Martins ${ }^{9}$
}

${ }^{1}$ Faculdade de Medicina São Leopoldo Mandic, Campinas, São Paulo, SP, Brazil

2 Faculdade de Medicina de Catanduva, Catanduva, São Paulo, SP, Brazil

3 Pontifícia Universidade Católica de São Paulo, Brazil

4 Faculdade de Medicina, Universidade Santo Amaro, São Paulo, SP, Brazil

5 Fellowship in Neurosurgery, Hospital Santa Paula, São Paulo,

São Paulo, SP, Brazil

${ }^{6}$ Department of Research and Innovation, Laboratory of Cellular and Molecular Biology, Faculdade de Medicina do ABC, Santo André,

São Paulo, SP, Brazil

7 Pain Center and Department of Neurosurgery, Hospital Santa Paula, São Paulo, São Paulo, SP, Brazil

${ }^{8}$ Department of Neurology, Faculdade de Medicina de Sorocaba, Pontifícia Universidade Católica de São Paulo, Sorocaba, São Paulo, SP, Brazil

${ }^{9}$ Peripheral Nerve Surgery Unit, Division of Functional Neurosurgery, Instituto de Psiquiatria, Faculdade de Medicina da Universidade de São Paulo, São Paulo, São Paulo, SP, Brazil

Address for correspondence Breno Alexander Bispo, Bachelor of Medicine, Rua Santo Antônio 431, apto. 93, Cambuí, Campinas, São Paulo, SP, Brazil (e-mail: brenobispo26@gmail.com).

Arq Bras Neurocir 2021;40(4):e380-e386.

\section{Abstract \\ Keywords \\ - facial paralysis \\ - facial anastomosis \\ - masseteric nerve \\ - nerve graft}

Intoduction The pathways of the facial nerve are variable, and knowledge of that is essential. The worst impact caused by facial paralysis is related to quality of life, especially regarding the self-esteem and social acceptance on the part of the patients, leading to social isolation and disruption on their mental health.

Case Report A 33-year-old female patient, with a stage-T3 acoustic neurinoma, presented with a moderate dysfunction (grades II to III) according to the HouseBrackmann (HB) Facial Nerve Grading System. A 43-year-old male patient, with a stageT4B trigeminal schwannoma, underwent a resective surgery and presented grade-VI dysfunction according to the HB scale. And a female patient with a stage-T4A acoustic neurinoma presented grade-IV dysfunction according to the HB scale.

Discussion We performed a literature review of papers related to surgeries for masseteric-facial nerve anastomosis and compiled the results in table; then, we compared these data with those obtained from our cases. received

August 9, 2020

accepted

February 22, 2021

published online

August 31, 2021
DOI https://doi.org/ $10.1055 / \mathrm{s}-0041-1730338$. ISSN 0103-5355.

\footnotetext{
(c) 2021. Sociedade Brasileira de Neurocirurgia. All rights reserved. This is an open access article published by Thieme under the terms of the Creative Commons Attribution-NonDerivative-NonCommercial-License, permitting copying and reproduction so long as the original work is given appropriate credit. Contents may not be used for commercial purposes, or adapted, remixed, transformed or built upon. (https://creativecommons.org/ licenses/by-nc-nd/4.0/) Thieme Revinter Publicações Ltda., Rua do Matoso 170, Rio de Janeiro, RJ, CEP 20270-135, Brazil
} 


\section{Resumo}

\section{Palavras-chave \\ - paralisia facial \\ - anastomose facial \\ - nervo massetérico \\ - enxerto de nervo}

Conclusion The masseteric nerve is the one that shows the best prognosis among all the cranial nerves that could be used, but it is also necessary to perform well the surgical technique to access the facial branch and consequently achieve a better masseteric-facial nerve anastomosis.

Intodução As vias do nervo facial são variáveis, e o conhecimento delas é essencial. 0 pior impacto causado pela paralisia facial está relacionado à qualidade de vida, principalmente no que se refere à autoestima e aceitação social dos pacientes, e leva ao isolamento social e a transtornos na saúde mental.

Relato de caso Paciente do sexo feminino, de 33 anos, com neurinoma acústico de estágio T3, apresentou disfunção moderada (graus II a III) na escala de nervo facial de House-Brackmann (HB). Paciente do sexo masculino, de 43 anos, portador de schwannoma trigeminal de estágio $\mathrm{T} 4 \mathrm{~B}$, foi submetido a cirurgia de ressecção do tumor e apresentou, no pós-operatório, disfunção de grau $\mathrm{VI}$ na escala de HB. E paciente do sexo feminino com neurinoma acústico de estágio T4A, apresentava disfunção de grau IV na escala de HB.

Discussão Realizamos uma revisão da literatura sobre os principais trabalhos relacionados às cirurgias de anastomose massetérico-facial, compilamos os resultados em uma tabela, e, em seguida, comparamos os dados obtidos com nossos casos.

Conclusão O nervo massetérico é o que apresenta melhor prognóstico entre todas os nervos cranianos que poderiam ser utilizados; entretanto, para isso é necessário realizar uma boa técnica cirúrgica para garantir um adequado acesso ao ramo facial e, consequentemente realizar uma melhor anastomose massetérico-facial

\section{Introduction}

The facial nerve (CN VII), is a mixed cranial nerve with motor, parasympathetic, and sensory branches; ${ }^{1}$ it is made up of four nuclei that serve different functions, such as: movement of muscles that produce facial expression; parasympathetic innervation to the lacrimal, submaxillary, and submandibular glands; the sensation of the external ear; and the sensation of taste. ${ }^{2}$ The pathways of the facial nerve are variable, and that knowledgement is essential to perform an accurate physical diagnosis and safe and effective surgical intervention in the head and neck.

This nerve is vulnerable to several injuries which can result in facial paralysis. Facial paralysis is one of the most common cranial neuropathies, and its main clinical repercussion in patients is a dysfunction in facial expression ${ }^{3}$. The facial paralysis can range from the slightest asymmetry to complete paralysis on one or both sides of the face, and can be classified through the House-Brackmann (HB) Facial Nerve Grading System, which was developed as an indicator of severity; however, it is also used as a progress record for facial paralysis treatments. The grades of involvement on this scale range from I to VI ( - Table 1 ); grades I and II have good outcomes, grades III and IV represent moderate dysfunction, and grades V and VI have bad outcomes. ${ }^{4}$

The worst impact caused by facial paralysis is related to quality of life, especially regarding the self-esteem and social acceptance on the part of the patients, leading to social isolation and disruption in their mental health. Moreover, facial paralysis increases the risk of corneal damage and infection. ${ }^{5}$ Therefore, several treatment options have emerged, including reanimation surgery via anastomosis. The surgical reanimation of facial movements and, above all, of the facial expression are a challenge for all microsurgeons, and knowledge of the surgical techniques becomes fundamental to provide the best treatment. In patients with facial paralysis, the local cranial nerves represent a good source of motor axons that can be redirected for facial reanimation. ${ }^{6}$ Besides that, masseteric-facial nerve anastomosis has been shown to be an excellent surgical treatment for the facial paralysis in the recent academic literature.

Masseteric-facial nerve anastomosis can be performed through a surgery to redirect the motor axons of the trigeminal cranial nerve (masseteric motor branch), which is extremely abundant in motor axons, to reverse and resuscitate the facial muscles, recovering facial expression. In the present paper, we report three cases of masseteric-facial anastomosis, and compare the data obtained from them with the data from a literature review on facial-anastomosis surgeries (- Table 2 ).

\section{Methods}

\section{Surgical Technique}

Under general anesthesia, a modified rhytidectomy incision is marked (as it provides good exposure and has the advantage of resulting in less complications and better cosmetic 
Table 1 Categorization of facial lesion through the House-Brackmann Facial Nerve Grading System

\begin{tabular}{|c|c|c|c|}
\hline Grade & Description & \multicolumn{2}{|c|}{ Characteristics } \\
\hline 1 & Normal & \multicolumn{2}{|c|}{ Normal facial function in all areas } \\
\hline \multirow[t]{3}{*}{ II } & \multirow[t]{3}{*}{$\begin{array}{l}\text { Mild } \\
\text { dysfunction }\end{array}$} & Gross: & $\begin{array}{l}\text { Slight weakness noticeable on close inspection; } \\
\text { may have very slight synkinesis }\end{array}$ \\
\hline & & At rest: & Normal symmetry and tone \\
\hline & & Motion: & $\begin{array}{l}\text { Forehead: moderate to good function } \\
\text { Eye: complete closure with minimal effort } \\
\text { Mouth: slight asymmetry }\end{array}$ \\
\hline \multirow[t]{3}{*}{ III } & \multirow[t]{3}{*}{$\begin{array}{l}\text { Moderate } \\
\text { dysfunction }\end{array}$} & Gross: & $\begin{array}{l}\text { Obvious but no disfiguring difference between two sides; noticeable } \\
\text { but not severe synkinesis, contracture, and/or hemifacial spasm }\end{array}$ \\
\hline & & At rest: & Normal symmetry and tonus \\
\hline & & Motion: & $\begin{array}{l}\text { Forehead: slight to moderate movement } \\
\text { Eye: complete closure with effort } \\
\text { Mouth: slightly weak with maximum effort }\end{array}$ \\
\hline \multirow[t]{3}{*}{ IV } & \multirow{3}{*}{$\begin{array}{l}\text { Moderately severe } \\
\text { dysfunction }\end{array}$} & Gross: & Obvious weakness and/or disfiguring asymmetry \\
\hline & & At rest: & Normal symmetry and tone \\
\hline & & Motion: & $\begin{array}{l}\text { Forehead: none } \\
\text { Eye: incomplete closure } \\
\text { Mouth: asymmetry with maximum effort }\end{array}$ \\
\hline \multirow[t]{3}{*}{$\mathrm{V}$} & \multirow{3}{*}{$\begin{array}{l}\text { Severe } \\
\text { dysfunction }\end{array}$} & Gross: & Only barely perceptible motion \\
\hline & & At rest: & Asymmetry \\
\hline & & Motion: & $\begin{array}{l}\text { Forehead: none } \\
\text { Eye: incomplete closure } \\
\text { Mouth: slight movement }\end{array}$ \\
\hline $\mathrm{VI}$ & Total paralysis & & No movement \\
\hline
\end{tabular}

outcomes $^{7}$ ), and epinephrine (dilution: $1: 200,000$ ) is infiltrated subcutaneously along the incision line. A point $3 \mathrm{~cm}$ anterior to the tragus and $1 \mathrm{~cm}$ inferior to the zygomatic arch (surface landmark for the masseteric nerve) is also marked. Skin flaps are elevated anteriorly to this point, and the greater auricular nerve is delineated in its entire course until its entry into the parotid gland ( - Figure 1 ). If the need arises, this can be used as an interposition nerve graft. The parotid gland is cut in half, and the entire facial nerve trunk, from its exit from the stylomastoid foramen and the first $2 \mathrm{~cm}$ of the main branches after bifurcation to the bucinator and obicularis oculi muscles, is exposed and divided close to the exit from the stylomastoid foramen (to gain additional nerve length for the anastomosis). The masseteric nerve is then identified with the zygomatic arch, the posterior border of the masseter muscle, and the lower part of the temporal nerve as standard landmarks. It is advisable to enter the masseter $\sim 1 \mathrm{~cm}$ anterior to the posterior border. As the nerve lies deep at the level of the lower border of the zygomatic arch, detachment of the masseter from the zygomatic arch is not necessary. Care must be taken to preserve the branches of the facial nerve over the masseter. The masseteric nerve lies $1.5 \mathrm{~cm}$ to $2.0 \mathrm{~cm}$ deep from the muscle surface within its belly closer to its internal surface than its external surface. Gentle dissection of the muscle fibers usually reveals the nerve, which courses from its origin deep into the zygomatic arch pointing toward the oral commissure. For the anastomosis, the proximal branches can be spared, preventing total denervation of the masseter muscle. ${ }^{8}$ The masseteric nerve is sectioned, and the anastomosis is performed directly to the most affected portion of the facial nerve (the mouth, the eye or even the main trunk). (-Figure 2)

\section{Case Report}

\section{First Case}

A 33-year-old female patient, with a stage-T3 acoustic neurinoma according to the Samii classification. ${ }^{9}$ The patient had a grade-IV to $\mathrm{V}$ facial paralysis on the right side, according to the HB scale (-Table 1). She was submitted to an elective surgery for tumor removal and radiotherapy (radiosurgery) in the meatal lesion, which decreased the grade of the paralysis to II to III according to the HB scale. After 9 months, she underwent another elective surgery for masseteric-facial nerve anastomosis, which resulted in full recovery of function four months postoperatively (-Figure 3 ).

\section{Second Case}

A 43-year-old male patient, with a stage-T4B trigeminal schwannoma. The patient underwent a resective surgery and presented grade-VI paralysis according to the HB scale. After sixmonths of the resective surgery, the patient underwent a hypoglossal-facial anastomosis surgery to improve facial function, which was not possible due to the technical conditions. 
Table 2 Summary of the literature review

\begin{tabular}{|c|c|c|c|}
\hline Author (year) & $\begin{array}{l}\text { Preoperative } \\
\text { HB grade (n) }\end{array}$ & Results & Conclusion \\
\hline $\begin{array}{l}\text { Bianchi et al. }{ }^{11} \\
(2018)\end{array}$ & HB VI (6) & $\begin{array}{l}4 \text { patients were evaluated as grade III in the } \\
\text { scale and } 2 \text { patients were evaluated as } \\
\text { grade II. }\end{array}$ & $\begin{array}{l}\text { The masseteric/cross facial nerve grafting } \\
\text { might be used in patients with palsies for } \\
20 \text { to } 24 \text { months and achieve great results. }\end{array}$ \\
\hline $\begin{array}{l}\text { Altamami et al. }{ }^{12} \\
(2019)\end{array}$ & $\mathrm{HB}$ VI (7) & $\begin{array}{l}\text { The masseteric anastomosis of the facial } \\
\text { nerve did not show improvement on } \\
\text { forehead movements; however, there was } \\
\text { some improvement in the movement of } \\
\text { the mouth and smile. }\end{array}$ & $\begin{array}{l}\text { The masseteric-facial nerve anastomosis is } \\
\text { a viable option for patients with facial } \\
\text { nerve paralysis. }\end{array}$ \\
\hline $\begin{array}{l}\text { Biglioli et al. }{ }^{15} \\
(2018)\end{array}$ & HB VI (24) & $\begin{array}{l}11 \text { patients were HB grade II postopera- } \\
\text { tively; } 11 \text { patients were HB grade III post- } \\
\text { operatively; and } 2 \text { patients were HB grade } \\
\text { IV postoperatively. }\end{array}$ & $\begin{array}{l}\text { This surgical technique showed to be safe } \\
\text { and effective, improving the degree of } \\
\text { paralysis. }\end{array}$ \\
\hline $\begin{array}{l}\text { Lee et al. }^{10} \\
(2020)\end{array}$ & Not available & $\begin{array}{l}3 \text { patients had an excellent resting } \\
\text { symmetry postoperatively, and all } 4 \text { had } \\
\text { good eye closure. } 3 \text { had good oral } \\
\text { excursion, and } 1 \text { had excellent. } 3 \text { patients } \\
\text { were evaluated with good smiles. } \\
2 \text { patients were evaluated with excellent, } \\
\text { and } 1 \text {, with good oral continence. }\end{array}$ & $\begin{array}{l}\text { The masseteric anastomosis shows good } \\
\text { results when it comes down to dynamic } \\
\text { facial motion. }\end{array}$ \\
\hline $\begin{array}{l}\text { Vincent et al. }{ }^{13} \\
\text { (2019) }\end{array}$ & $\begin{array}{l}\text { HB III or } \\
\text { IV (7) }\end{array}$ & HB scores ranged from II to III & $\begin{array}{l}\text { After masseteric facial nerve transfer, the } \\
\text { patients evolved with significant improve- } \\
\text { ment in smile symmetry and lower facial } \\
\text { synkinesis as measured with the eFace tool. }\end{array}$ \\
\hline $\begin{array}{l}\text { Sakthivel et al. }{ }^{8} \\
(2020)\end{array}$ & HB VI (6) & $\begin{array}{l}1 \mathrm{HB} \text { I, } 2 \text { patients } \mathrm{HB} \text { II and } 3 \text { patients } \\
\mathrm{HB} \mathrm{V}\end{array}$ & $\begin{array}{l}\text { Compared to other techniques masseteric } \\
\text { facial nerve anastomosis is a versatile } \\
\text { powerful early facial dynamic reanimation } \\
\text { tool with almost negligible morbidity for } \\
\text { patients with complete facial nerve } \\
\text { paralysis. }\end{array}$ \\
\hline $\begin{array}{l}\text { Gray et al. }{ }^{17} \\
(2020)\end{array}$ & HB V or VI (8) & $\begin{array}{l}\text { Preoperative smile deviation in commis- } \\
\text { sure excursion of } 8.8 \mathrm{~mm} \text {, and a postop- } \\
\text { erative deviation of } 3.8 \mathrm{~mm} \text {. The deviation } \\
\text { angle of the smile improved from } \\
10.3 \text { degrees to } 5.2 \text { degrees. }\end{array}$ & $\begin{array}{l}\text { Single-stage masseteric-zygomatic nerve } \\
\text { transfer is a useful procedure for patients } \\
\text { with synkinesis caused by facial nerve } \\
\text { paralysis. }\end{array}$ \\
\hline $\begin{array}{l}\text { Hontanilla et al. }{ }^{16} \\
(2018)\end{array}$ & Not available & $\begin{array}{l}\text { Spontaneous recovery of the smile during } \\
\text { more than } 50 \% \text { of the patient's daily life } \\
\text { was of } 80 \% \text { in the group submitted to } \\
\text { cross-facial nerve grafting, and of } 55.5 \% \text { in } \\
\text { group submitted to masseteric-facial nerve } \\
\text { anastomosis, which, surprisingly pre- } \\
\text { sented a higher degree of satisfaction. }\end{array}$ & $\begin{array}{l}\text { With the masseteric nerve, better sym- } \\
\text { metry, a higher degree of recovery, and an } \\
\text { increased level of satisfaction are achieved } \\
\text { in a single-stage operation. Furthermore, } \\
\text { both nerve sources are able to restore } \\
\text { spontaneity in more than } 50 \% \text { of the } \\
\text { patient's daily life, with no significant } \\
\text { differences between them. }\end{array}$ \\
\hline $\begin{array}{l}\text { Mohanty et al. }{ }^{18} \\
(2018)\end{array}$ & $\begin{array}{l}\mathrm{HB} \text { VI (3) } \\
\mathrm{IV}(1)\end{array}$ & $\begin{array}{l}\text { Motion was observed } 8 \text { days after external } \\
\text { neurolysis of the neurovascular bundle in } \\
\text { patient } 1 \text {, and } 4 \text { months in the second free } \\
\text { functional muscle transfer group (patients } \\
2,3 \text {, and } 4 \text { ). The average excursion and } \\
\text { philtral correction were of } 11.2 \mathrm{~mm} \text { and } \\
2.39 \mathrm{~mm} \text { respectively. }\end{array}$ & $\begin{array}{l}\text { Reusing the masseteric nerve to innervate } \\
\text { another free functional muscle transfer is a } \\
\text { feasible and reliable option if there are no } \\
\text { obvious contraindications to another free } \\
\text { functional muscle transfer and masseter } \\
\text { muscle contraction is clearly demonstrable } \\
\text { preoperatively. }\end{array}$ \\
\hline
\end{tabular}

Abbreviation: HB, House-Brackmann Facial Nerve Grading System.

Subsequently, a masseteric-facial anastomosis surgery was attempted, which, unfortunately, even after 2 years, did not achieve good results, and the patient remained with altered facial function, with grade-VI paralysis on the HB scale.

\section{Third Case}

A female patient with a stage-T4A acoustic neurioma; after the resective surgery, she presented grade-IV paralysis on the $\mathrm{HB}$ scale, that is, a significant impairment in facial function. She was submitted to a masseteric-facial nerve anastomosis surgery, and, two months postoperatively, presented grade-III paralysis on the HB scale, being able to close the eyes more and smile somewhat more widely, expressing excellent surgical results.

\section{Discussion}

Incomplete facial paralysis still remains a surgical challenge. Techniques such as masseteric-facial anastomosis are 


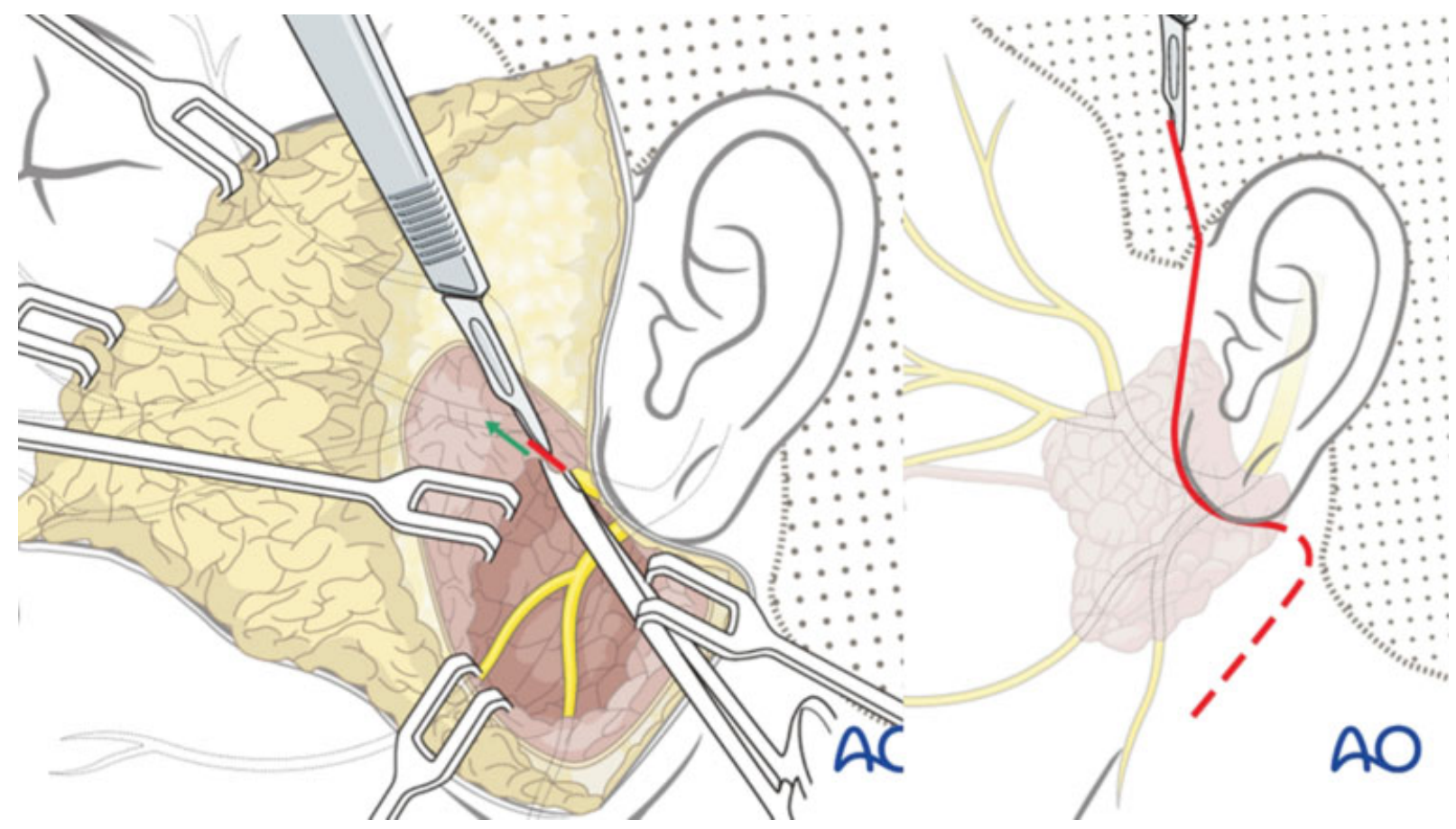

Fig. 1 Representation of the surgical incision and the division of the branches of the facial nerve (CN VII) in the parotid gland. ${ }^{19}$
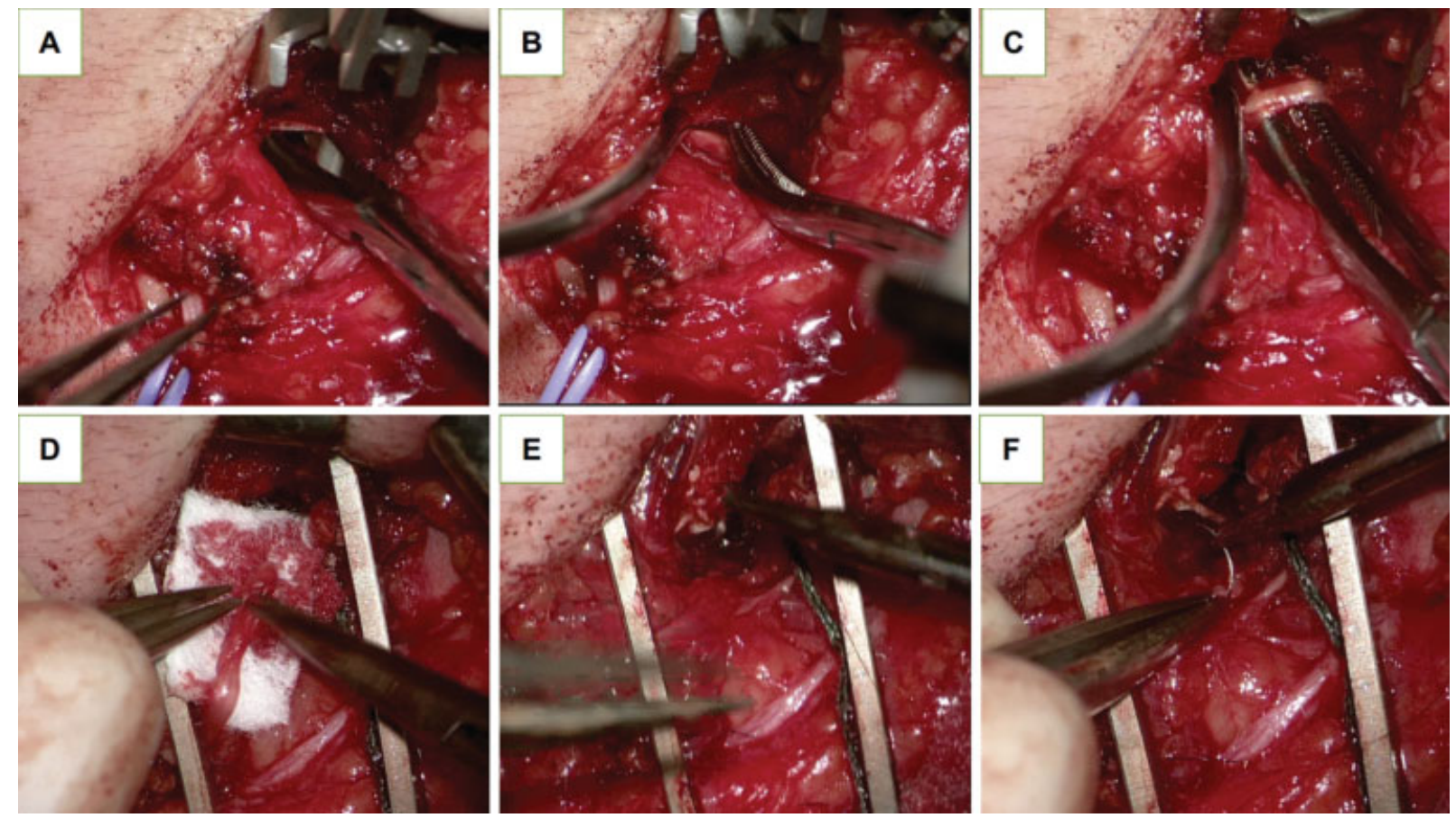

Fig. 2 (A) Surgical Approach using the modified rhytidectomy incision; (B) opening of the masseteric facia; (C) inspection of the masseteric nerve; (D) anastomosis of the masseteric nerve; (E) inspection of the preservation of the other nerves; (F) sucture procedures.

gaining popularity and showing good results. We performed a literature review on the main papers related to massetericfacial nerve anastomosis surgeries and compiled the results obtained in - Table 2 .

We compared the data obtained from the literature with the data from our cases. In our first case, the patient had a moderate dysfunction (grades II to III on the HB scale), and, just four months after the masseteric-facial anastomosis, she evolved to complete recovery of function. Analyzing the third case, one can see that an excellent evolution has also occurred, for the patient, who had a moderately severe dysfunction (grade IV on the HB scale), evolved to grade III in two months, and was able to close the eyes more and smile somewhat more widely. Unfortunately, this did not happen with our second case, who, even after two years of the masseteric-facial anastomosis, did not show a significant 


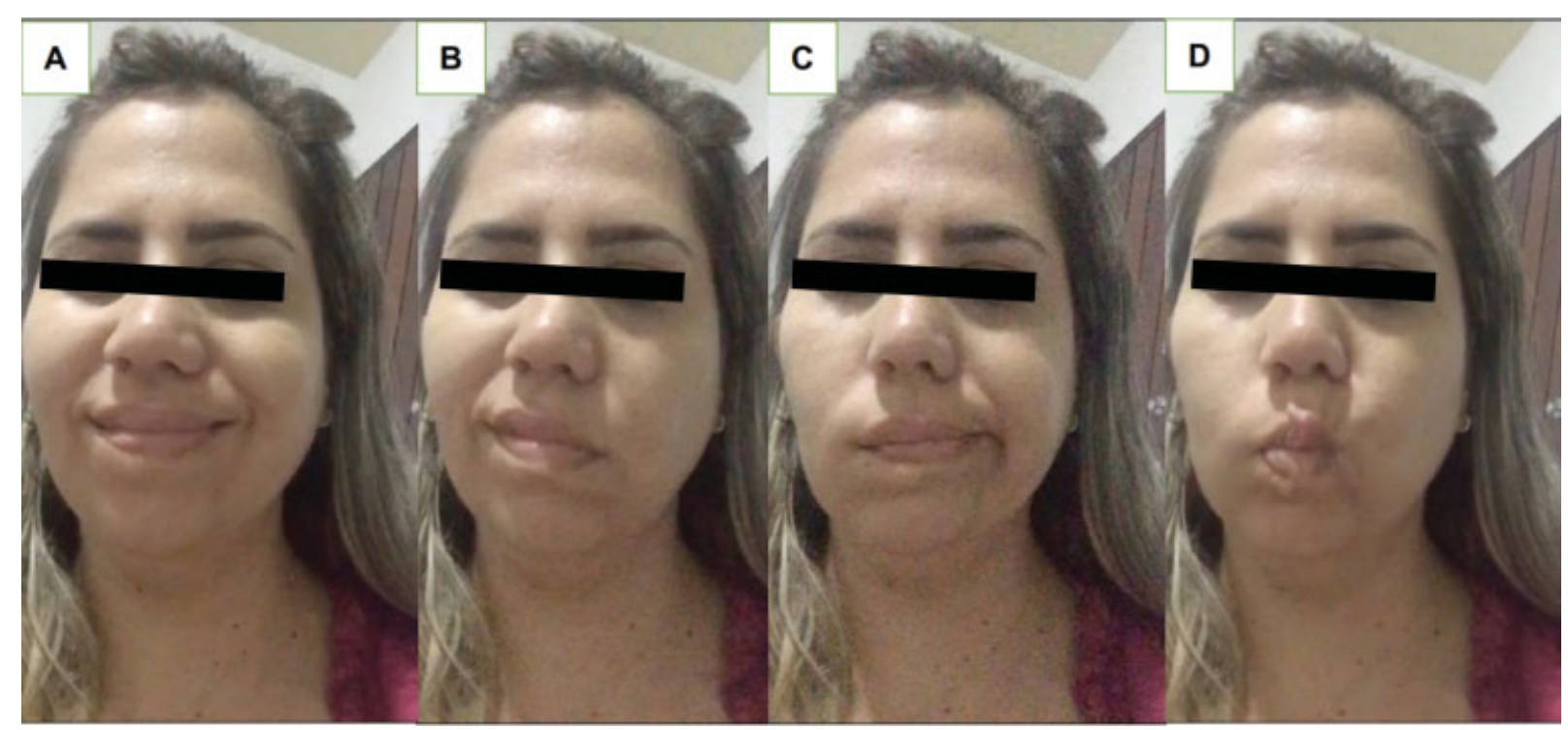

Fig. 3 (A) Bilateral and harmonious movement of the facial muscles four months after the surgery; (B) normal movement of the face muscles on the right side four months after the surgery; (C) normal movement of the muscles of the left side (unaffected side); (D) bilateral and harmonious movement of the facial muscles four months after the surgery.

evolution. Considering the three cases herein reported, the third had a good outcome, the first had an excellent outcome and fast evolution, and the second presented bad outcome; therefore two out of three patients presented good evolution.

Our results corroborate with those of Lee et al. ${ }^{10}(2020)$, who reported that $75 \%$ of the patients who underwent masseteric innervation obtained excellent results regarding the symmetry of the face at rest. They also included in their results an improvement in the ability to close the eyes, in the movement of the mouth, and in the ability to smile. We can also mention the studies by Bianchi et al. ${ }^{11}$ (2018) and Altamami et al. ${ }^{12}$ (2019), in which recovery was successful, with the patients evolving from grade VI preoperatively to grades lower tahn IV on the HB scale after masseteric-facial nerve anastomosis. However, Vincent et al. ${ }^{13}$ (2019) found no statistically significant difference in their study, but suggest that masseteric-to-facial nerve transfer with selective neurectomy provides a significant improvement in the ability to smile, with a long-term decrease in synkinesis among patients unresponsive to botulinum toxin therapy or who, for other reasons, do not wish to continue with regular injections.

In addition, Biglioli et al. ${ }^{14}$ (2018) presented a new surgical technique for the treatment of patients with segmental midface paresis (with or without synkinesis). This method comprises two surgeries with a gap of one year between them, which consist of a masseteric neurorrhaphy combined with cross-face nerve grafting. Of the 20 patients in the study, 8 presented muscular contracture at rest in the middle third of the face preoperatively, and, postoperatively, partial-to-complete relaxation of the middle face was observed in all of these cases. In the preoperative period, synkinesis was present in 11 of the 20 patients, and, after the surgery, it was completely resolved in 7 patients; in 3 patients, synkinesis was reduced, although it was still present in response to more intense stimuli than in the preoperative period; and, in 1 out of 11 patients, synkinesis remained present and showed no improvement. Moreover, in another study, Bigioli et al. ${ }^{15}$ (2018), analyzed 24 patients with dense unilateral facial palsy (HB grade VI) who underwent surgery between January 2013 and February 2016. The surgery employed was a new technique with triple neural inputs: the use of the masseteric nerve and 30\% of the hypoglossus nerve fibers as quantitative sources was associated with the contralateral facial nerve (incorporated via two cross-face nerve grafts) as a qualitative source. In all patients, the facial paralysis improved, as did their grades on the HB scale. Recovery of the facial paralysis showed it first signs two to eight months after surgery, and continued through the entire postoperative period. During an 18-month follow-up period, the median grade of those 24 patients was III on the modified HB scale: 11 patients (45.83\%) were grade II; 11 patients (45.83\%), grade III; and 2 (8.33\%), grade IV. Both studies showed that other surgical techniques can be used for the treatment of facial paralysis; however, masseteric-facial anastomosis is still being performed as an important step in the recovery of these patients. To compare two different surgical techniques, the cross-facial nerve grafting (CFNG) and the masseteric-facial nerve anastomosis, mainly used in the aforementioned papers, Hontanilla et al. ${ }^{16}$ (2018) divided the 28 patients in their sample into 2 groups: 10 in group 1 (patients submitted to CFNG) and 18 in group 2 (patients submitted to masseteric-facial nerve anastomosis). In total, $80 \%$ of the CFNG group had spontaneous recovery of their smiles during more than $50 \%$ of their daily lives. In contrast, in group 2, the recovery was of just $55.5 \%$. Nevertheless, satisfaction with the treatment was greater among group 2. This paper also showed that, with the masseteric-facial nerve anastomosis, better symmetry can be achieved, with a greater recovery and a higher degree of satisfaction on the part of the patients.

Sakthivel et al. ${ }^{8}$ (2020) described the surgical technique and the effectiveness of the masseteric nerve in early facial reanimation. All patients in their sample underwent end-to- 
end anastomosis, except for one, in whom a greater auricular interposition graft was used. In all cases, the facial muscles showed signs of recovery in 2 to 5 months, when movement of the cheek musculature was noticed when the patients activated their masseter muscle. Eye movement started appearing after 6 to 9 months (in 3 cases), and forehead movements, after 18 months (in 1 case). According to the modified HB scale, one patient had grade-I function, two patients had grade-II function, and three had grade-V function. There was no morbidity, except for one patient who underwent interposition graft and had numbness in the ear lobule. None of the patients could feel the loss of function of the masseteric nerve. Additionally, in the study by Gray et al. ${ }^{17}$ (2020), 8 patients with eye closure or smile excursion synkinesis were submitted to the surgery, with results that made the authors realize that the single-stage masseteric-zygomatic nerve transfer is a useful procedure for patients with synkinesis caused by facial nerve paralysis.

\section{Conclusion}

Due to the obstruction of the innervation of the facial muscles by tumor growth, masseteric-facial nerve anastomosis, after the removal of the tumor, had to be performed for the total reinnervation of such muscles and the skin in the cases herein reported. The masseteric nerve is the one that shows the best prognosis among all the cranial nerve that could be used, due to its efficient neuroplasticity, and the rapid and effective motor rehabilitation of the facial muscles. However, this fact alone does not lead to a better prognosis when compared with the other cases in the literature, it is also necessary to perform the surgical technique well to access the facial branch, and consequently perform a better masseteric-facial anastomosis.

\section{Conflict of Interest}

The authors have no conflict of interests to declare.

\section{References}

1 Toulgoat F, Sarrazin JL, Benoudiba F, et al. Facial nerve: from anatomy to pathology. Diagn Interv Imaging 2013;94(10):1033-1042. Doi: 10.1016/j.diii.2013.06.016

2 Sanders RD, Gillig PM. The trigeminal (V) and facial (VII) cranial nerves: Head and face sensation and movement. Psychiatry (Edgmont Pa) 2010;7(01):13-16

3 Batista KT, Cauhi AF. Surgical rehabilitation for facial paralysis. Rev Bras Cir Plást 2007;22(04):253-260
4 House JW, Brackmann DE. Facial nerve grading system. Otolaryngol Head Neck Surg 1985;93(02):146-147. Doi: 10.1177/0194 59988509300202

5 Davies J, Al-Hassani F, Kannan R. Facial nerve disorder: a review of the literature. Int J Surg Oncol (NY) 2018; 3(07):e65. Doi: 10.1097/ IJ9.0000000000000065

6 Jeziorowski A, Tirapelle R, Saciloto A, et al. Masseteric-facial anastomosis on treatment of facial palsy. ACM Arq Catarin Med 2007;36(sulp. 1):165-168

$7 \mathrm{Xu}$ ZJ, Chen LS, Zhan JD, et al. [Modified rhytidectomy incision and modified Blair incision contrast research in superficial parotid gland tumor resection]. Lin Chung Er Bi Yan Hou Tou Jing Wai Ke Za Zhi 2017; 31(21):1684-1687. Doi: 10.13201/j.issn.1001-1781.2017.21.015

8 Sakthivel P, Singh CA, Thakar A, Thirumeni G, Raveendran S, Sharma SC. Masseteric-Facial Nerve Anastomosis: Surgical Techniques and Outcomes-A Pilot Indian study. Indian J Otolaryngol Head Neck Surg 2020;72(01):92-97. Doi: 10.1007/s12070-019-01758-z

$9 \mathrm{Wu} \mathrm{H}$, Zhang L, Han D, et al. Summary and consensus in 7th International Conference on acoustic neuroma: An update for the management of sporadic acoustic neuromas. World J Otorhinolaryngol Head Neck Surg 2016;2(04):234-239. Doi: 10.1016/j. wjorl.2016.10.002

10 Lee YS, Ahn JH, Park HJ, et al. Dual Coaptation of Facial Nerve Using Masseteric Branch of Trigeminal Nerve for Iatrogenic Facial Palsy: Preliminary Reports. Ann Otol Rhinol Laryngol 2020;129(05): 505-511. Doi: 10.1177/0003489419893722

11 Bianchi B, Varazzani A, Pedrazzi G, et al. Masseteric cooptation and crossfacial nerve grafting: Is it still applicable 22 months after the onset of facial palsy? Microsurgery 2018;38(08):860-866. Doi: $10.1002 /$ micr.30296

12 Altamami NM, Zaouche S, Vertu-Ciolino D. A comparative retrospective study: hypoglossofacial versus masseterofacial nerve anastomosis using Sunnybrook facial grading system. Eur Arch Otorhinolaryngol 2019;276(01):209-216. Doi: 10.1007/s00405018-5186-y

13 Vincent AG, Bevans SE, Robitschek JM, Wind GG, Hohman MH. Masseteric-to-Facial Nerve Transfer and Selective Neurectomy for Rehabilitation of the Synkinetic Smile. JAMA Facial Plast Surg 2019;21(06):504-510. Doi: 10.1001/jamafacial.2019.0689

14 Biglioli F, Soliman M, El-Shazly M, et al. Use of the masseteric nerve to treat segmental midface paresis. Br J Oral Maxillofac Surg 2018;56(08):719-726. Doi: 10.1016/j.bjoms.2018.07.023

15 Biglioli F, Allevi F, Rabbiosi D, et al. Triple innervation for reanimation of recent facial paralysis. J Craniomaxillofac Surg 2018; 46(05):851-857. Doi: 10.1016/j.jcms.2018.02.014

16 Hontanilla B, Olivas J, Cabello Á, Marré D Cross-Face Nerve Grafting versus Masseteric-to-Facial Nerve Transposition for Reanimation of Incomplete Facial Paralysis: A Comparative Study Using the FACIAL CLIMA Evaluating System. Plast Reconstr Surg 2018;142(02):179e-191e. Doi: 10.1097/PRS.0000000000004612

17 Gray ML, Hu S, Gorbea E, Mashkevich G. Masseteric-zygomatic nerve transfer for the management of eye closure-smile excursion synkinesis. [published online ahead of print, 2020 Apr 4]Am J Otolaryngol 2020;41(04):102479. Doi: 10.1016/j.amjoto. 2020.102479 